\title{
Cycloderma frenatum Peters 1854 - Zambezi Flapshell Turtle, Nkhasi
}

\section{Donald G. Broadley ${ }^{1}$ And Walter SachSse ${ }^{2}$}

\author{
${ }^{1}$ Natural History Museum of Zimbabwe, \\ P.O.Box 240, Bulawayo, Zimbabwe [broadley@gatorzw.com]; \\ ${ }^{2}$ Institut für Molekulargenetik SBII, Saarstrasse 21, \\ 55099 Mainz, Germany [waltersachsse@aol.com]
}

\begin{abstract}
Summary. - The Zambezi Flapshell Turtle, Cycloderma frenatum (Family Trionychidae), is a fairly large softshell (carapace length up to about $56 \mathrm{~cm}$ ) from southeastern Africa. It is found in rivers and lakes from southern Tanzania south to the Save River in Mozambique, extending west to Lake Malawi (Nyasa), where it is common in the shallower areas at the southern end of the lake. These are fast swimming, completely aquatic turtles of about $37-50 \mathrm{~cm}$ shell length, which are mostly caught as bycatch in large nets by local fishermen. In areas with human settlements, the nests are excavated during the breeding season (December-March) and the 15-25 eggs per clutch are consumed.

Distribution. - Malawi, Mozambique, Tanzania,Zimbabwe. East Africa from the Rufiji River basin in Tanzania south to the Save River basin in Mozambique and southeastern Zimbabwe, inland to Lakes Malawi, Chiuta, and Chilwa.

Synonymy. - Cycloderma frenatum Peters 1854, Cyclanosteus frenatus, Heptathyra frenata, Aspidochelys livingstonii Gray 1860, Heptathyra livingstonii.

SubSPECIES. - None.

STATUS. - IUCN 2011 Red List: Near Threatened (NT, assessed 1996, needs updating); CITES: Not Listed; South African Red Data Book: Not Listed.
\end{abstract}

Taxonomy. - Although Cycloderma frenatum was briefly described from material from the Zambezi River in Mozambique by Wilhelm Peters in 1854, his comprehensive description and illustrations of the species did not appear until 1882 in the Reise nach Mossambique series. In the meantime, J.E. Gray (1860) described Aspidochelys livingstonii from "tributaries of the Zambezi River,Mozambique", distinguished by the nature of the plastral callosities, but he subsequently realized that these developed with age and subsequently synonymized $A$. livingstonii with $C$. frenatum (Gray 1870).

Cycloderma frenatum is readily distinguished from its only recent congener, C.aubryi, by its olive-gray coloration, in contrast to the dark reddish brown of the latter. It also

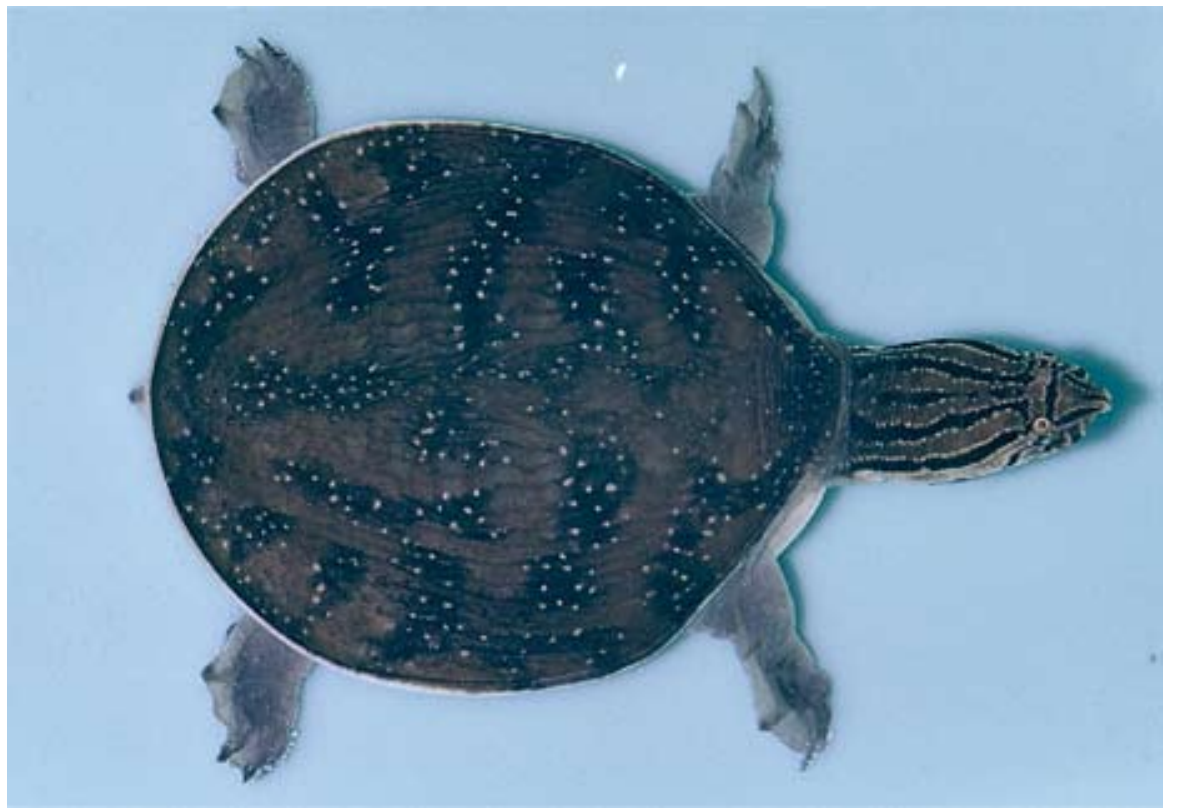

Figure 1. Juvenile Cycloderma frenatum from Lake Malawi. Photo by Wulf Haacke. 


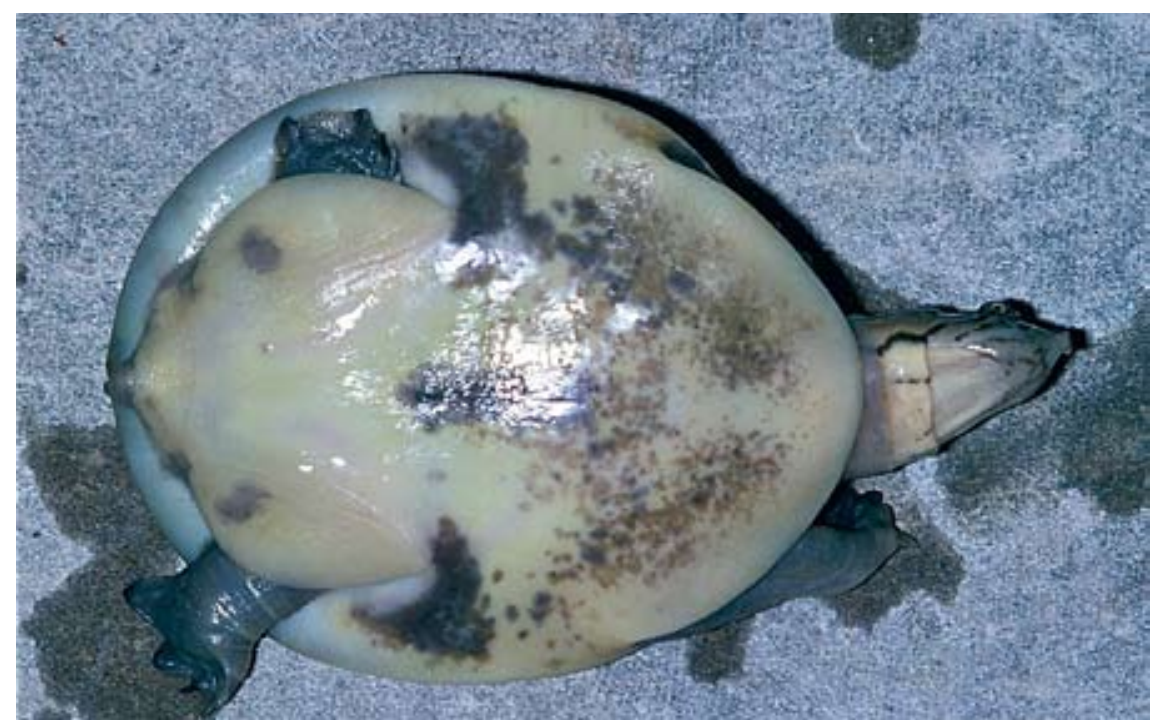

Figure 2. Juvenile Cycloderma frenatum from Lake Malawi. Photo by Wulf Haacke.

differs in its reduced plastral callosities, the entoplastral one being very small and the hyo-hypoplastral callosities being separated from the xiphiplastal callosities or barely touching them. It differs from the two extinct species, $C$. victoriae and $C$. debroinae, in its very reduced entoplastral callosity and the distal border of the first costal being much longer than that of the second costal (Meylan et al. 1990).

Description. - The proboscis is projecting, the distance from its tip to the orbit equal to the orbital diameter (in young), or longer (in adults). Nostrils have papilla-like processes projecting upwards from their inframedian corner. The upper lips meet anteriorly to form a flat arch laterally, sharply angled in vertical aspect. The head and neck can be shot forward with high velocity to almost the length of the carapace. The forefeet have four or five sharp-edged crescentic skin folds on their upper surface, and another weal-like thickening on their outer aspect; whereas the hind feet have sharp-edged crescentic folds under the heel posterior to the base of the fifth toe. The tail is rudimentary,

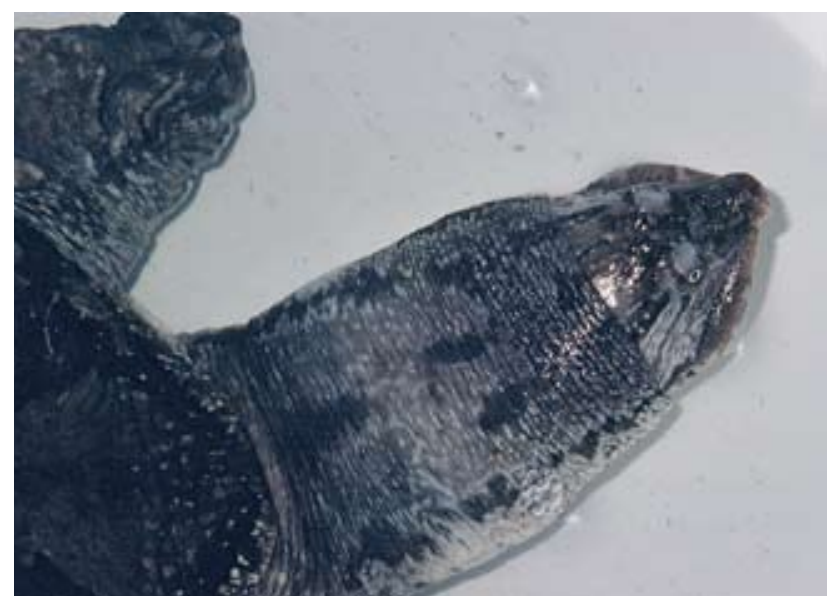

Figure 3. Adult Cycloderma frenatum from the Rovuma River, on the border between Tanzania and Mozambique. Photo by Stephen Spawls. slightly projecting beyond the posterior leathery rim of the carapace in males, but not in females.

The carapace of the young has a moderate vertebral keel and numerous wavy longitudinal ridges, whereas the adult carapace is smooth in live specimens. The leathery margin is not extensive posteriorly, barely extending beyond tail. When dried, the adult carapace displays the underlying bony sculpturing. The plastron of hatchlings is smooth, without callosities (in the young these first appear as small pairs on the epiplastra, hyo-hypoplastra, and xiphiplastra, while the last to develop is the azygous element on the entoplastron). The femoral and caudal flaps of the plastron permit the concealment of hind limbs and tail.

The osteology is comprehensively described by Loveridge and Williams (1957). There are seven plastral callosities, sculptured like the carapace, and very well developed in adults. Epiplastral callosities have large oblique ovals, in contact medially. The entoplastron bears a small, crescentic to semilunarcallosity, smallest of any and the last to develop. Hyo-hypoplastral callosities cover most of the surfaces of the bones and spread beyond their borders, separated medially. Hyo-hypoplastral callosities are separated from the xiphiplastral callosities, or are in contact by only a short suture. Xiphiplastral callosities have large oblique ovals, which are in contact medially (Loveridge and Williams 1957).

Loveridge and Williams (1957) noted thatPeters described his Zambezi type material as dark green in color, whereas 21 juveniles and 11 adults from Lake Malawi and the Rovuma River included pale gray to leaden hatchlings and pale to dark olive adults. Specimens from southeastern Zimbabwe are olive brown, so there does not seem to be a latitudinal trend in coloration. The carapace of Lake Malawi hatchlings ranges from pale green to leaden, the periphery usually edged with white. The plastron of Lake Malawi hatchlings is often almost white, usually with an irregular black blotch present in the umbilical region, an elongate, oblique blotch near each forelimb, a more rounded one anterior to each hind limb, and a smaller sixth spot in the anal region. The adult carapace is 


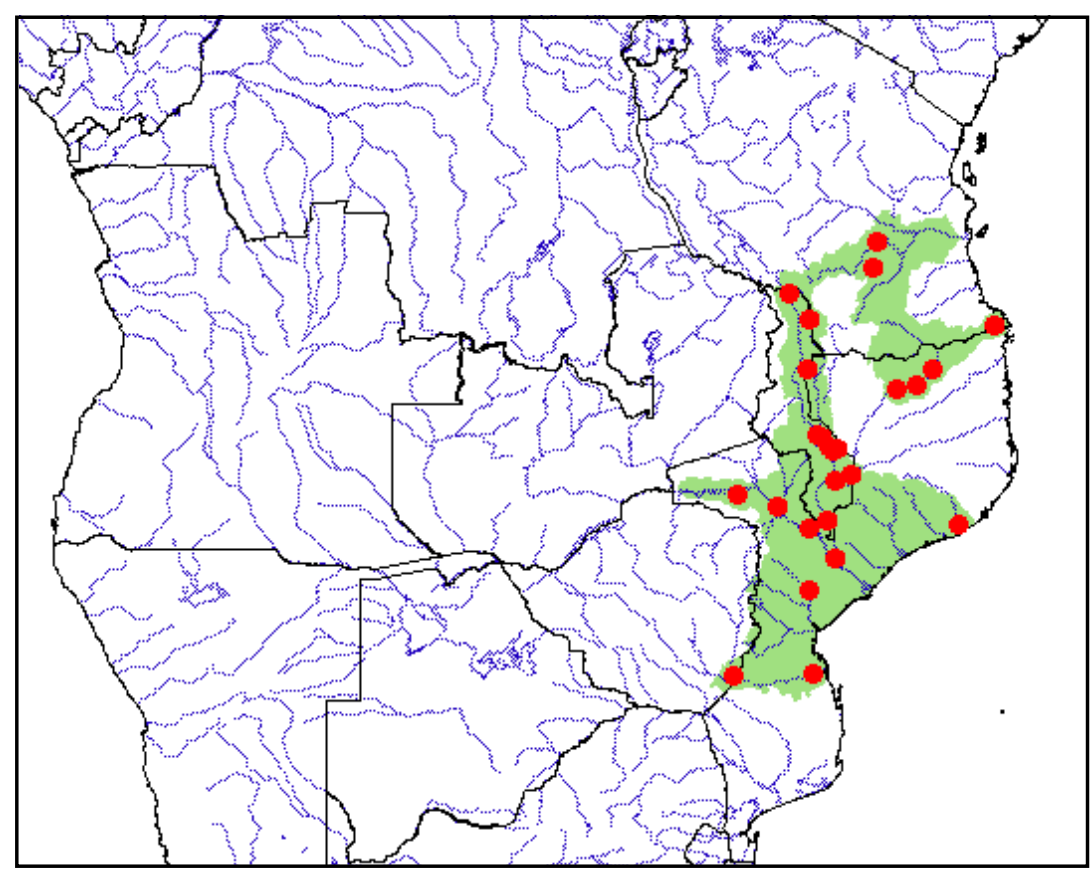

Figure 4. Distribution of Cycloderma frenatum in Malawi, Mozambique, Tanzania, and Zimbabwe in southeastern Africa. Red dots = museum and literature occurrence records of native populations based on Iverson (1992) and Gramentz (2008) plus more recent and authors' data; green shading = projected distribution based on GIS-defined hydrologic unit compartments (HUCs) constructed around verified localities and then adding HUCs that connect known point localities in the same watershed or physiographic region, and similar habitats and elevations as verified HUCs (Buhlmann et al. 2009), and adjusted based on authors' data.

pale to dark olive, uniform, or with a trace of blotching. The plastron of adult females is china-white to flesh-pink, almost obscured by pearly gray reticulations. These reticulations are sometimes absent in what may be males.

The head and neck in Lake Malawi hatchlings are gray with a dark, light-edged, interorbital crossbar, and five similar, but wavy and sometimes broken, longitudinal lines from near the occiput to the base of the long neck. The throat and underside of the neck are pure white, uniform, or showing some dusky streaks. The head and neck of adults are very dark olive, the dark longitudinal lines of the young turtle obscured or, more usually, absent. Peters (1882), writing of Zambezi turtles, stated that the head and neck in both age groups displayed numerous white dots. The feet are gray above and lighter below.

The curvilinear carapace length (CL) of a Zambezi male was $560 \mathrm{~mm}$, the bony disk alone was $470 \mathrm{~mm}$, its width $420 \mathrm{~mm}$ (Peters 1882), whose figures do not quite tally, for he gives the total length as $970 \mathrm{~mm}$, though head and neck together were only $340 \mathrm{~mm}$ and the tail $65 \mathrm{~mm}$. Overall linear CL of three Malawi females averaged about $560 \mathrm{~mm}$, width $418 \mathrm{~mm}$. The head and neck of one (MCZ 50357) measured $420 \mathrm{~mm}$; the breadth of the head $100 \mathrm{~mm}$. The bony disk length of the largest gravid Rovuma female (MCZ 48030) was $390 \mathrm{~mm}$, its width (also without leathery margin, $310 \mathrm{~mm}$ (Loveridge 1942, 1953). Overall CL of 31 Lake Malawi hatchlings was $40-48 \mathrm{~mm}$, their width 30-36 $\mathrm{mm}$. Peters (1882) mentioned a Zambezi hatchling of 45 $\mathrm{mm}$. The mass of the largest Zambezi male was $13-14 \mathrm{~kg}$ (Peters 1882); that of the largest Rovuma female was 11.4 $\mathrm{kg}$ (Loveridge 1942).
The sex of adults, though not of young, may be distinguished by the fact that the tail of the male is visible in ventral view (Peters 1882, pl. I), while that of the female is concealed beneath the caudal flap (Peters 1882, pl. IIIa, Fig. 1). Peters claimed that the carapace is relatively narrower in males than in females (the relative proportions noted to be $1: 1.33$ and 1:1.25) and that the bridge between the carapace and plastron is longer in males than in females. When relaxed in the water, the tail tip of the male is a bit longer than the rim of the carapace and is carried bent upwards.

Distribution. - The center of the range for Cycloderma frenatum seems to be Lake Malawi (Mitchell 1959) in Malawi, Mozambique, and Tanzania. It extends down the Shire River into the Zambezi, but its upstream distribution in this river appears to be limited by the Cahora Bassa rapids. Athough Pitman (1934) listed this species as "believed to occur" in Northern Rhodesia (= Zambia), the remains that he observed in the Luangwa valley "which indicate that there are specimens which may attain 2 feet in length and a weight of 20 to $30 \mathrm{lbs"} \mathrm{may} \mathrm{have} \mathrm{been} \mathrm{another} \mathrm{turtle}$ species, possibly large specimens of Pelusios sinuatus. If Cycloderma occurred in the Middle Zambezi system, it would surely have been caught by fishermen and reported. Gramentz (2008) maps an alleged record of $C$. frenatum from southeastern Zambia, citing the species as occurring at Chowe, but this locality is on Lake Malombe in southern Malawi (Loveridge 1953).

The species extends south across the Mozambique Plain to the Save River and enters southeastern Zimbabwe in the Gonarezhou National Park (Broadley 1962, 1984). In the Save River, its upstream limit is the Chivirira Falls; 
however, in the Runde River it has reached beyond the Chitove Falls and occurs up to the Chiviriga Falls (Broadley 1990). To the north of the Zambezi and east of the Shire River and Lake Malawi, $C$. frenatum has been reported from Lakes Chilwa and Chiuta in Malawi (Mitchell 1959), via the Lugenda River (draining Lake Chiuta) in the Niassa Game Reserve (Branch 2003), to the lower Rovuma River at Kitaya in Tanzania (Loveridge 1942). It also occurs in the the Kilombero River (a tributary of the Rufiji River) in central Tanzania (Loveridge 1942).

Fossil material of this species has been recorded from the Pleistocene Omo beds to the north of Lake Turkana (Arambourg 1947; Lapparent de Broin 1979) and from the Pliocene beds of Lothagam Hill and Koobi Fora in the Lake Turkana basin (Meylan et al. 1990). Additional fossils are known from the Pliocene Chiwondo beds towards the northern end of Lake Malawi (Meylan et al. 1990).

Habitat and Ecology. - Cycloderma frenatum seems to prefer sandy rather than muddy substrates (Mitchell 1959). Sachsse (pers. obs.) regards this species as a highly specialized fish-catcher, feeding on mussels only when fish are not available. The mechanism of catching fish is essentially the same as in Chitra, but the snapping speed is not quite as fast. Juvenile turtles lay completely concealed in the sand with only the eyes protruding, and shoot out of this position for a fish. When adult animals see prey, they approach very slowly and snap as soon as the length of the neck will allow it. The large hyoid bones support the abrupt sucking mechanism. In southern Lake Malawi, adult turtles feed to a large extent on mussels (Caelatura nyassensis, Mutela alata, and M. simpsoni) and large aquatic snails (Lanistes ellipticus and $L$. sordidus) (Loveridge 1953; Mitchell 1959). Such feeding habits might be age dependent. Kenmuir (1980) found that, in Lake Kariba, mussels were abundant at depths of 3-9 m, but occurred down to $11 \mathrm{~m}$. Mussels probably occur at similar depths in the lakes and rivers inhabited by Cycloderma, so turtles are probably not common where the water is more than $10 \mathrm{~m}$ deep. Mussels are dug out from the substrate of rivers and lakes, using the powerful claws on the forefeet. The shells are crushed in the jaws and swallowed, but undamaged valves are sometimes defecated by newly caught specimens (Mitchell 1946). No data are available on growth or longevity for wild specimens.

In Lake Malawi, adult turtles may travel several kilometers from shore and, on days of dead calm, up to half a dozen can usually be seen floating on the surface basking in the sun (Mitchell 1959). These turtles have been found moving overland during daylight in the Gorongosa National Park in Mozambique (K. Tinley, pers. comm.) and in southeastern Zimbabwe (C. Stockil, pers. comm.)

In Lake Malawi, female turtles come ashore at night to lay their eggs between the end of January and April. The nest site is in the shade under trees and bushes, usually within 200 $\mathrm{m}$ of the water. A clutch of 17-25 eggs is laid in a shallow excavated nest hole. The eggs are hard-shelled, spherical, and $33-35 \mathrm{~mm}$ in diameter. The incubation period is $8-11$ months and hatchlings emerge the following January. The hatching period lasts for only about three weeks, although nesting occurs over a 10 -week period. Hatchlings are plentiful in January and may be found under loose stones and logs along the high-water mark (Mitchell 1959). On the Rovuma River, a female with a bony disk length of $390 \mathrm{~mm}$ contained 17 eggs of $32 \mathrm{~mm}$ diameter on 27 April, the following day another female held 19 eggs of $31 \mathrm{~mm}$ diameter (Loveridge 1942).

Leeches are present on turtles from the Rovuma River and Lake Malawi (Loveridge 1942, 1953). Adults are consumed by crocodiles, whereas the young are likely taken by the Nile Monitor (Varanus niloticus) and various predatory birds (Mitchell 1959).

Population Status. - This species seems to be common in the southern shallow half of Lake Malawi, but is rare in the deep waters of the northern half of the lake (Mitchell 1959). No declines have yet been reported anywhere in its range.

Threats to Survival. - There appears to have been reasonably common domestic capture and consumption of the species by local tribes in the past. In 1949, Loveridge saw scores of eggshells on village middens around Mtimbuka, southern Lake Malawi. When they came ashore to construct nests, female turtles were easy prey for local people (Loveridge 1953). Taylor (1962) noted that Cycloderma were eaten by the Shangaan tribe in southeasternZimbabwe and adjacent Mozambique. Broadley (pers.obs.) recovered carapaces from Shangaan village middens near the Save-Runde confluence before the establishment of the Gonarezhou National Park. Cycloderma were netted by the Shangaans in their annual fish drives (Broadley 1962). Whether this domestic consumptiuon is still prevalent at present is unknown. There is apparently no commercial exploitation or international trade of this species at this time.

Conservation Measures Taken. - Some populations are protected in the Lake Malawi, Gorongosa, and Zinave National Parks and Niassa Game Reserve in Mozambique, as well as Gonarezhou National Park in Zimbabwe. The species is listed as Near Threatened on the IUCN Red List, having been assessed in 1996.

Conservation Measures Proposed. - Native populations need to be monitored for population size and survival status. Monitoring for potential development of international trade should be carried out opportunistically. The global status of the species on the IUCN Red List needs to be reassessed.

Although this species occurs in several National Parks, consideration might be given to introducing the species into the Middle Zambezi system, where suitable habitats are available in two large artificial impoundments, lakes Kariba and Cahora Bassa (Broadley 1990). Lake Kariba is at approximately the same level as Lake Malawi (ca. 550 m ASL), whereas Lake Cahora Bassa is lower, at ca. 400 m ASL, so climatic conditions are similar. If the Wild Life authorities in Zimbabwe or Mozambique were in favor of a 
trial introduction of Cycloderma into either of these lakes, one of the numerous crocodile farms on both lakes could incubate the eggs and headstart the hatchlings. If such an introduction were to be considered, then ecological monitoring of potential impacts on fish and invertebrate fauna would need to be carried out.

Captive Husbandry. - Young flapshell turtles can be kept completely aquatic, as they grow they should have an island of cork bark. The water should be maintained at $24-32^{\circ} \mathrm{C}\left(\max\right.$. range $\left.19-34^{\circ} \mathrm{C}\right)$, with a tenth to half a promille of sea salt, partly filled with floating plants, for which strong illumination (natural or artificial) is necessary. The bottom of the tank should be covered by a layer of fine sand about 1.5 times the diameter of the animals. They should be fed a variety of whole fish, dead laboratory mice, and pieces of gelatin food prepared for aquatic chelonians. Mitchell found that captive hatchlings from Lake Malawi eagerly took fine strips of fish or meat from his fingers (Loveridge and Williams 1957). In captivity, they grow a bit faster than other softshell turtles, from the hatchling stage to $\mathrm{CL}=35 \mathrm{~cm}$ in 20-30 years. They are very susceptible to microbial infections of uncertain origin, to which they quickly succumb. For several months, two turtles lived in a small garden pond at Salima, Malawi. Normally, they did not rise to the surface between 1600 and 0830 hrs. During the daytime, however, they spent long periods with the tips of their snouts protruding from the water. They would only try to escape during rainy weather, or when the water in the pond was changed, prompting nocturnal emergence (Mitchell 1946). When they grow large one must be carefully observe pugnacious incompatibilities.

Current Research. - None known.

Acknowledgments. - Stephen Spawls and WulfHaacke kindly provided photographs.

\section{LITERATURE CITED}

ARAMBOURG, C. 1947. Contribution a l'étude géologique et paléontologique du bassin du Lac Rudolphe et de la basse vallée de l'Omo. In: Mission Scientifique de L'Omo(1932-1933). Deuxieme Partie, Paléontologie I (Geologie-Anthropologie). Fasc. 3. Paris: Museum National d'Histoire Naturelle, pp. 231-562.

BRANCH, W.R. 2003. Herpetological Survey of the Niassa Game Reserve. Report prepared for Sociedade para a Gestão e Desenvolvimento da Reserva do Niassa, Moçambique. Port Elizabeth: Bayworld.

BROADLEY,D.G. 1962.On some reptile collections from the northwestern and northeastern districts of Southern Rhodesia 1958-1961, with descriptions of four new lizards. Occasional Papers of the National Museum of Southern Rhodesia, Ser B. 4(26):787-843.

Broadley, D.G. 1984. The Nkhasi or Zambezi soft-shelled turtle. Hartebeest 15:8-11.

BROADLEY, D.G. 1990. The Zambezi flapshelled turtle or Nkhasi. Zimbabwe Science News 24(10/12):100-101.

Buhlmann, K.A., Akre, T.S.B., Iverson, J.B., Karapatakis, D., MitTERMEIER, R.A., Georges, A., Rhodin, A.G.J., vAN DiJK, P.P., AND GiBBons, J.W. 2009. A global analysis of tortoise and freshwater turtle distributions with identification of priority conservation areas. Chelonian Conservation and Biology 8(2):116-149.

Gramentz, D. 2008. African Flapshell Turtles. Cyclanorbis and $C y$ cloderma. Frankfurt am Main: Edition Chimaira, 191 pp.

GRAY,J.E. 1860.Description of a soft tortoise(Aspidochelys livingstonii) from the Zambesi, sent to the British Museum by Dr. Livingstone. Proceedings of the Zoological Society of London 1860:5-6.

GraY,J.E. 1870. Supplement to the Catalogue of Shield Reptiles in the Collection of the British Museum. Part I. Testudinata (Tortoises). London, $120 \mathrm{pp}$.

IVERSON,J.B. 1992.ARevised Checklist with Distribution Maps of the Turtles of the World. Richmond, IN: Privately published, 363 pp.

KENMUIR,D.H.S. 1980.Aspects of the biology and population dynamics of freshwater mussels in Lake Kariba and Lake McIlwaine. Lake Kariba Fisheries Research Institute Project Report No. 36. Ph.D. Thesis, University of Natal.

Lapparent de Broin, F. 1977. Chélonians du Miocéne et du PlioPléistocene d'Afrique orientale. Bulletin de la Société Géologique de France (7)21:323-327.

LOVERIDGE, A. 1942. Scientific results of a fourth expedition to forested areas in East and Central Africa. IV. Reptiles. Bulletin of the Museum of Comparative Zoology 91:238-373.

LoverIDGE, A. 1953. Zoological results of a fifth expedition to East Africa. III. Reptiles from Nyasaland and Tete. Bulletin of the $\mathrm{Mu}-$ seum of Comparative Zoology 110:141-322.

Loveridge, A. AND Williams, E.E. 1957. Revision of the African tortoises and turtles of the suborder Cryptodira. Bulletin of the Museum of Comparative Zoology 115:163-557.

Meylan, P.A., Weig, B.S., And Wood, R.C. 1990. Fossil soft-shelled turtles (Family Trionychidae) of the Lake Turkana Basin, Africa. Copeia 1990:508-528.

MrTCHELL,B.L.1946.Anaturalist in Nyasaland.Nyasaland Agricultural Quarterly Journal 6:1-47.

MrtCHELL, B.L. 1959. Some notes on the Nkhasi or Nyasa soft-shelled turtle (Cycloderma frenatum). Journal of the Herpetological Association of Rhodesia 6:5-6.

PETERS, W.K.H.1854.Ubersichtderauf seinerReise nach Mossambique beobachteten Schildkröten. Monatsberichte der Verhandlungen der Königlichen Preussischen Akademie der Wissenschaften zu Berlin 1854:215-216.

PETERS, W.K.H. 1882. Naturwissenschaftliche reise nach Mossambique auf Befehl seiner Majestät des Königs Friedrish Wilhelm IV in den Jahren 1842 bis 1848 ausgeführt. Zoologie, 3, Amphibien. Berlin, 191 pp.

PItMAn, C.R.S. 1934. A checklist of Reptilia and Amphibia occurring and believed to occur in Northern Rhodesia. In: Pitman, B.R.S. Report on a Faunal Survey of Northern Rhodesia. Livingstone: Government Printer, 500 pp.

TAYLOR, P. 1962. Shangaan herpetology. Journal of the Herpetological Association of Rhodesia 19:11-12.

\section{Citation Format for this Account:}

BROADLEY,D.G.ANDSACHSSE,W.2011.Cycloderma frenatum Peters 1854 - Zambezi Flapshell Turtle, Nkhasi. In: Rhodin, A.G.J., Pritchard, P.C.H., van Dijk, P.P., Saumure, R.A., Buhlmann, K.A., Iverson, J.B., and Mittermeier, R.A. (Eds.). Conservation Biology of Freshwater Turtles and Tortoises: A Compilation Project of the IUCN/SSC Tortoise and Freshwater Turtle Specialist Group. Chelonian Research Monographs No. 5, pp. 055.1-055.5, doi:10.3854/crm.5.055 frenatum.v1.2011, http:// www.iucn-tftsg.org/cbftt/. 